http://jmscr.igmpublication.org/home/ ISSN (e)-2347-176x ISSN (p) 2455-0450 crossref DOI: https://dx.doi.org/10.18535/jmscr/v8i3.23

\title{
Implications of Glaucoma Management on Corneal Endothelial Cell Density - Two Edged Sword
}

\author{
Authors \\ Dr Preeti Rawat ${ }^{1}$, Dr Varun Upadhyay ${ }^{2}$, Dr V Bhaisare ${ }^{3}$, Dr S. Walia ${ }^{4}$, Dr Neetu Kori ${ }^{5}$ \\ ${ }^{1,3,4}$ Professor, Dept of Ophthalmology MGM Medical College Indore MP India \\ ${ }^{2}$ PG Resident, Dept of Ophthalmology, MGM medical college Indore MP 452001 INDIA \\ ${ }^{5}$ Assistant Professor, Dept of Ophthalmology MGM Medical College Indore MP India
}

\begin{abstract}
Purpose: To study the effect of glaucoma management on corneal endothelial cell density.

Method: Our study included 112 eyes of 65 diagnosed cases of glaucoma of same age group who underwent visual acuity test, IOP measurement, Gonioscopy, Fundus examination and specular microscopy analysis. Exclusion criteria included history of corneal disease, diabetes mellitus, any ocular inflammation, trauma or surgery other than peripheral iridectomy.

Observations and Results: Patients who underwent PI or Trabeculectomy were found to have significantly lower cell density $\left(2080 \pm 263\right.$ cells $\left./ \mathrm{mm}^{2}\right)$ than those without any surgical or laser intervention $(2474 \pm 362$ cells $\left./ \mathrm{mm}^{2}\right)(p=0.000)$. Although statistically insignificant, but patients on 3 or 4 anti glaucoma medications were having lower cell density than those on 1 or 2 medication.

Conclusion: In our study it is evident that cell density is lower in glaucoma patients than those without glaucoma. This may be proposed to direct damage from high IOP, post trabeculectomy or iridectomy cell loss, medication toxicity or combination of these. So while achieving target pressure benefit-risk ratio of endothelial cell density decompensation should be mandatorily considered.

Keywords: Glaucoma, Endothelial cell density, laser PI, Trabeculectomy.
\end{abstract}

\section{Introduction}

The corneal endothelium is critical in maintaining a healthy and clear cornea and due to their limited regenerative capacity, preservation of these cells is paramount. ${ }^{1}$ Under stress, these cells enlarge to maintain corneal clarity but once ECD drops below a critical level, the underlying corneal functional reserve may be insufficient to maintain the appropriate corneal hydration status and corneal clarity. ${ }^{2}$

At birth, humans start with an endothelial cell density (ECD) of 5000-6000 cells $/ \mathrm{mm}^{2}$ and by adulthood have $2500-3000$ cell $/ \mathrm{mm}^{2}$ with cells arrested in the G1 phase of the cell cycle. Between the ages of 15 and 85 years, normal corneas lose $0.6 \%$ of ECD centrally per year. ${ }^{2}$

Glaucoma is associated with deleterious effects on the corneal endothelium. which may be caused by the disease process itself as well as by its treatment. It may be associated with certain morphological changes like decrease in cell density, pleomorphism, changes in cellular coefficient of variation and increase in central corneal thickness. $^{3}$

Glaucoma is worldwide prevalent and is common in population aged 40-80 years, with many of these patients undergoing varied levels of medical and surgical treatments to prevent progression of 
glaucoma, often with unintended and unknown consequences on the corneal endothelium. ${ }^{4}$ For example, higher rates of corneal endothelial cell loss have been reported with surgical glaucoma shunts ${ }^{5}$ and a history of glaucoma is one of the most important factors responsible for the reduced survival of corneal grafts. ${ }^{6}$

Therefore, understanding of the mechanism involved in glaucoma-associated damage to the corneal endothelium due to disease itself and its management is important for protecting corneal clarity and visual acuity in all glaucoma patients.

\section{Material and Methods}

It was a scientific and ethical committee approved cross sectional observational study which included 112 eyes of 65 diagnosed cases of glaucoma above 40 years of age. Patient younger than 40 years of age were excluded to limit the natural effect of ageing on corneal endothelial cell counts. Patient with a history of corneal disease, diabetes mellitus, contact lens wear, Uveitis, ocular trauma, ocular surgery (other than trabeculectomy), documented iris-cornea or lens-cornea touch were also excluded.

Endothelial cell density and central corneal thickness was measured using non contact specular microscope (konansp 330).Cell borders of a minimum of 100 cells per cornea were digitised to calculate coefficient of variation (standard deviation of mean cell / mean cell area, having a normal value of 0.25 ) and hexagonality of endothelial cells.
Results are expressed as means \pm standard deviations. Two-tailed student's $\mathrm{t}$ test and analysis of variance were used to compare means.

\section{Results}

A total of65patients consented for the study who were divided into two groups based on history of either interventional management (trabeculectomy and laser PI) or medical management. There were no significant differences among the two groups for mean age, gender, or overall disease duration. The demographic profile of the two groups showed a female predominance in each group with mean age in the range of 40 to 70 years. (Table 1)

With respect to management, in patients on whom any intervention was done (trabeculectomy or Laser iridotomy) cell density was observed to be significantly reduced $\left(2080 \pm 263\right.$ cells $\left./ \mathrm{mm}^{2}\right)$ as compared to those patients in whom no surgical or laser intervention was done $(2474 \pm 362$ cells $\left./ \mathrm{mm}^{2}\right) \quad(\mathrm{p}=0.000)$ (Table 2). However when both these interventions (trabeculectomy and laser) were analysed separately, the data did not reach statistical significance because of small number of patients in this subgroup $(\mathrm{p}=0.5)$ (Table 3).

Although statistically insignificant cell density in patients on 3 or 4 topical anti glaucoma medications $\left(2264 \pm 444\right.$ cells $\left./ \mathrm{mm}^{2}\right)$ was found to be lower than those on 1 or 2 topical anti glaucoma medications. $\left(2391 \pm 365\right.$ cells $\left./ \mathrm{mm}^{2}\right)$. (p-0.12). (Table 4)

Table 1: Demographic data

\begin{tabular}{|l|c|c|c|}
\hline & $\begin{array}{c}\text { Patient on interventional (trabeculectomy } \\
\text { or laser PI) management }\end{array}$ & $\begin{array}{c}\text { Patient on medical } \\
\text { management }\end{array}$ & $\begin{array}{c}\text { P } \\
\text { value }\end{array}$ \\
\hline Mean Age (in years) & $60.18 \underline{+20.04}$ & $58.42+18.42$ & \\
\hline Female/Male (\%) & $61.5 / 38.46$ & $58.45 / 41.55$ & \\
\hline
\end{tabular}

Table 2: Comparison of Mean Cell Density of Patients Having H/O Laser PI Or Trabeculectomy with those on Medical Management.

\begin{tabular}{|l|c|c|c|c|}
\hline & $\begin{array}{c}\text { NO.OF } \\
\text { CASES (n) }\end{array}$ & $\begin{array}{c}\text { NO. OF } \\
\text { EYES (N) }\end{array}$ & $\begin{array}{c}\text { MEAN CELL } \\
\left.\text { DENSITY (cells/mm }{ }^{2}\right)\end{array}$ & P VALUE \\
\hline Laser PI + Trabeculectomy & 20 & 34 & $2080 \pm 263$ & \multirow{2}{*}{.000} \\
\hline Medical Management & 45 & 78 & $2474 \pm 362$ & \\
\hline
\end{tabular}




\section{JMSCR Vol||08||Issue||03||Page 145-148||March}

Comparison of cell density in patients having prior history of surgical or laser intervention showed significant cell reduction in cell density in comparison to those who had no history of either of these.

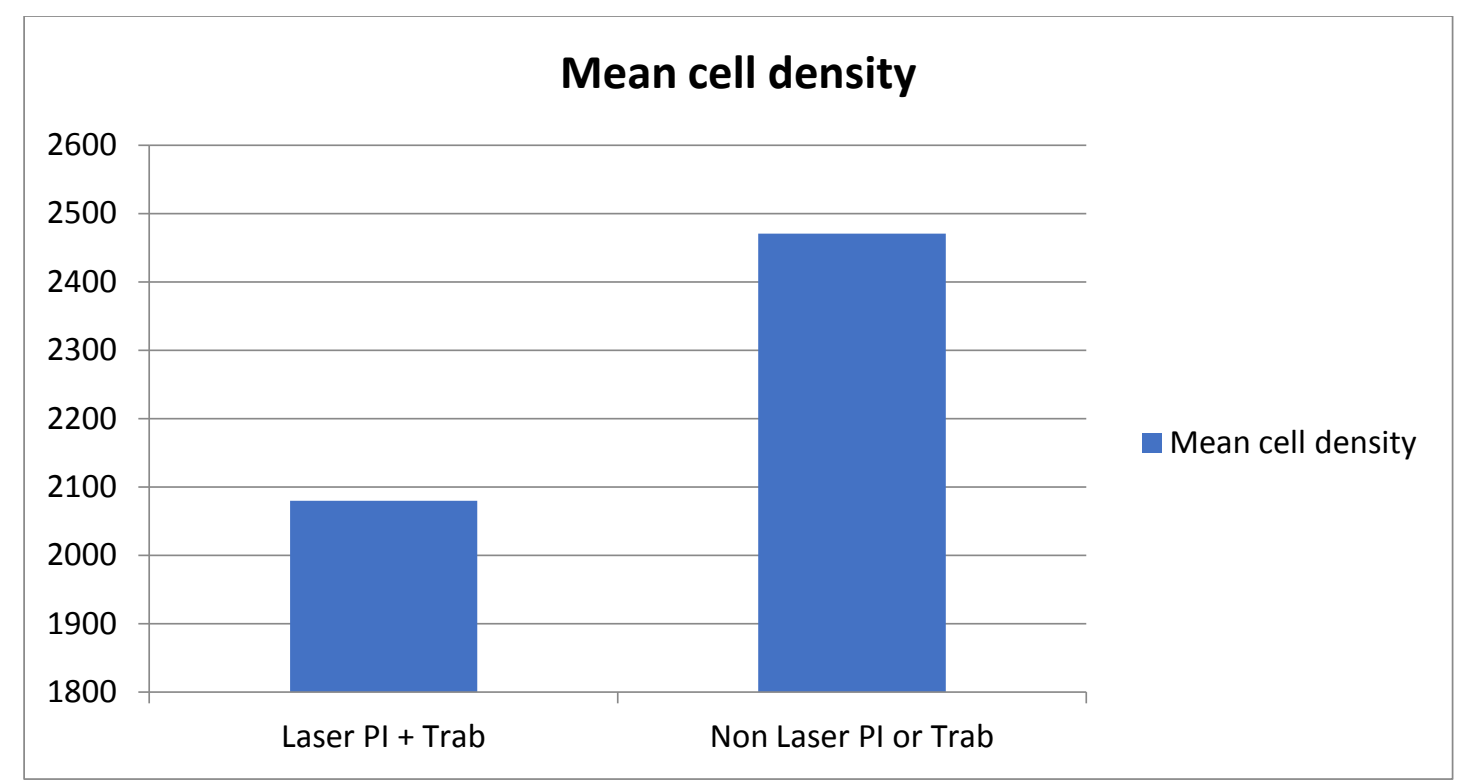

Graph 2: Comparison of Mean Cell Density of Patients Having H/O Laser PI or Trabeculectomy with those on Medical Management

Table 3: Comparison of Endothelial Cell Density in Patients of Laser PI and Trabeculectomy

\begin{tabular}{|l|c|c|c|c|}
\hline & NO.OF CASES (n) & NO.OF EYES (N) & MEAN CELL DENSITY (cells/mm & P value \\
\hline Laser PI & 10 & 17 & $2231.00 \pm 346.31$ & \multirow{2}{*}{.505} \\
\hline Trabeculectomy & 10 & 17 & $2152.58 \pm 331.24$ & \\
\hline
\end{tabular}

Comparison of cell density revealed no statistical significant difference in patients who have undergone laser PI in comparison to those who have undergone trabeculectomy

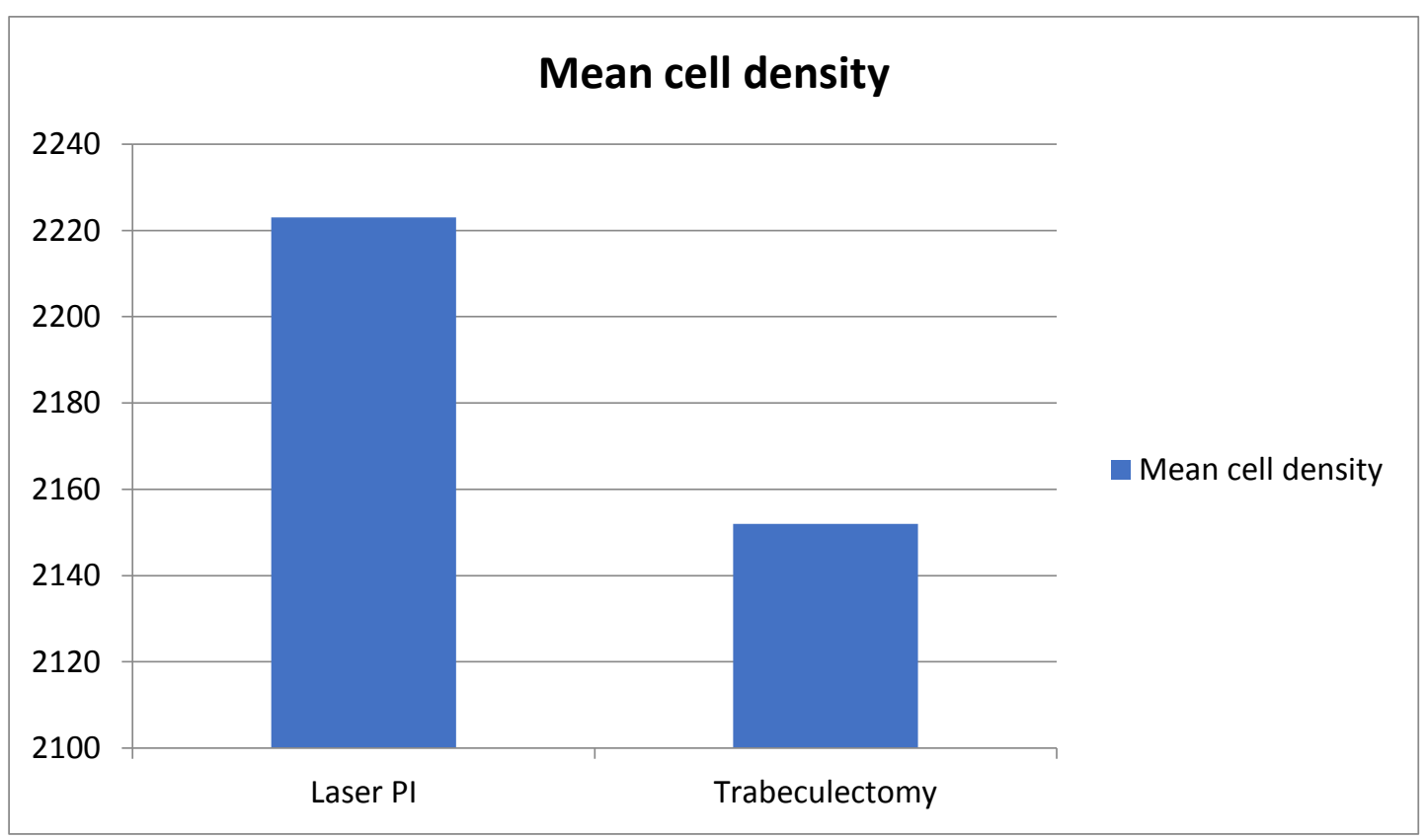

Graph 3: Comparison of Cell Density in Laser PI and Trabeculectomy Patients 
Table 4: Comparison of Cell Density of Cases (Excluding Patients with H/O Trabeculectomy or Laser Pi) on Basis of Number of topical anti glaucoma medication

\begin{tabular}{|c|c|c|c|c|}
\hline $\begin{array}{l}\text { no. of topical anti } \\
\text { glaucoma }\end{array}$ & no. of cases (n) & no. of eyes (n) & $\begin{array}{c}\text { mean cell density } \\
\left(\text { cells } / \mathbf{m m}^{2}\right)\end{array}$ & $p$ value \\
\hline 1 or 2 & 39 & 68 & $2391 \pm 365$ & \multirow{2}{*}{0.12} \\
\hline 3 or 4 & 6 & 10 & $2264 \pm 444$ & \\
\hline
\end{tabular}

\section{Discussion}

Our study demonstrated lower cell densities and high central corneal thickness inpatients on 3 or 4 topical anti glaucoma medication as compared to those on 1 or 2 topical anti glaucoma medication. This was supported by the study carried out by Baratz et al ${ }^{8}$ who found approximately similar reduction rate in medically treated corneas as compared to normal corneas.

Following trabeculectomy or laser iridotomy endothelial cell density was observed to be statistically insignificantly lower as compared to those without any surgical or laser intervention (analysed separately) which correlated with the study carried out by Kim et $\mathrm{al}^{9}$ and Gagnon et al ${ }^{7}$ respectively. However considering both trabeculectomy and laser iridotomy as a single intervention group and then comparing it with those in which no trabeculectomy or laser intervention was done, cell density reduction in intervention group was found to be statistically significant.

\section{Conclusion}

Endothelial cell loss in patients of glaucoma and also in patients undergoing any medical or surgical treatment for glaucoma may be attributed to direct damage from high IOP, toxic effects of topical medications, cell loss during surgery or combination of these. Therefore it is safe to conclude that while managing a patient of glaucoma we should prevent the unintentional and unwanted damage to the corneal endothelium.

\section{References}

1. Edelhauser HF. The balance between corneal transparency and edema: the Proctor Lecture. Invest Ophthalmol Vis Sci.2006;47:1754e67.
2. Aldrich BT, Schlotzer-Schrehardt U, Skeie $\mathrm{JM}$, et al. Mitochondrial and morphologic alterations in native humancorneal endothelial cells associated with diabetes mellitus. Invest Ophthalmol Vis Sci. 2017;58:2130e8

3. Janson BJ, Alward WL, Kwon YH, et al. Glaucoma-associated corneal endothelial cell damage: a review. Surv Ophthalmol 2018; 63: 500-506.

4. Jonas JB, Aung T, Bourne RR, et al. Glaucoma. Lancet.2017; 390:2183e93

5. Arnavielle S, Lafontaine PO, Bidot S, et al. Corneal endothelialcell changes after trabeculectomy and deep sclerectomy.J Glaucoma. 2007;16:324e8

6. Anshu A, Price MO, Price FW. Descemet's strippingendothelial keratoplasty: long-term graft survival and riskfactors for failure in eyes with pre-existing glaucoma. Ophthalmology. 2012;119:1982e7

7. Gagnon MM, Boisjoly HM, Brunette I, et al. Cornealendothelial cell density in glaucoma. Cornea. 1997; 16:314e8.

8. Baratz KH, Nau CB, Winter EJ, et al. Effects of glaucoma medications on corneal endothelium, keratocytes, and subbasal nerves among participants in the ocular hypertension treatment study. Cornea. 2006;25:1046e52.

9. Kim MS, Kim KN, Kim CS. Changes in corneal endothelial cell after Ahmed glaucoma valve implantation and trabeculectomy: 1-year follow-up. Korean J Ophthalmol.2016;30:416e25. 